\title{
PENGARUH AKTIVITAS LITERASI MATEMATIKA TERHADAP KEMAMPUAN BERPIKIR KRITIS KELAS IV
}

\author{
Rilo Eko Pambudi ${ }^{1}$,Soewalni Soekirno ${ }^{2}$, Ema Butsi Prihastari ${ }^{3}$ \\ ${ }^{1}$ Fakultas Keguruan dan Ilmu Pendidikan, Universitas Slamet Riyadi Surakarta \\ Email: $\underline{\text { riloekop19@gmail.com }}{ }^{1}$
}

\begin{abstract}
Research aimed to determine the influence of mathematical literacy activities on the ability of critical thinking in class IV mathematics of State Elementary School 3 Karanganyar where the research was conducted in the elementary School of Negeri 3 Karanganyar. This research sample was a class IV student numbering 36 children. This type of research used quantitative types. Data collection Techniques used: (1) tests; (2) Observation; (3) Documentation; (4) interviews. The data analysis technique used is the technique of Paired sample T-Test. Based on the results of the test Paired sample T-Test obtained that the value of Thitung $24.24>$ This at a rate of significance 5\% of 1.69. Thus, there is the influence of mathematical literacy activities on the ability of critical thinking in class IV mathematics of State Elementary School 3 Karanganyar Year lesson 2019/2020 can be accepted the truth in a significant. Summed up, implementing mathematical literacy activities can help develop critical thinking skills. It is recommended to implement mathematical literacy practice activities. For learners to solve mathematical problems with critical thinking skills.
\end{abstract}

Keywords: mathematical literacy activities, critical thinking ability of the aproksimation material

\begin{abstract}
Abstrak
Tujuan penelitian untuk mengetahui pengaruh aktivitas literasi matematika terhadap kemampuan berpikir kritis pada Mata Pelajaran Matematika Kelas IV Sekolah Dasar Negeri 3 Karanganyar Tempat penelitian dilaksanakan di Sekolah Dasar Negeri 3 Karanganyar. Sampel penelitian ini adalah peserta didik kelas IV berjumlah 36 anak. Jenis penelitian menggunakan jenis kuantitatif. Teknik pengumpulan data yang digunakan: (1) tes; (2) observasi; (3) dokumentasi; (4) wawancara. Teknik analisis data yang digunakan adalah teknik Paired Sample $t$ Test. Berdasarkan hasil uji Paired Sample t-test diperoleh bahwa nilai $t_{\text {hitung }}$ sebesar 24,24 $>\mathrm{t}_{\text {tabel }}$ pada taraf signifikansi 5\% sebesar 1,69. Sehingga, terdapat pengaruh aktivitas literasi matematika terhadap kemampuan berpikir kritis pada mata pelajaran matematika kelas IV Sekolah Dasar Negeri 3 Karanganyar Tahun Pelajaran 2019/2020 dapat diterima kebenaran secara signifkan. Disimpulkan, penerapan aktivitas literasi matematika dapat membantu mengembangkan kemampuan berpikir kritis. Disarankan menerapkan aktivitas literasi matematika dan latihan soal. Agar peserta didik mampu menyelesaikan permasalahan matematika dengan kemampuan berpikir kritis.
\end{abstract}

Kata Kunci : Aktivitas Literasi Matematika, Kemampuan Berpikir Kritis Materi Aproksimasi, 


\section{PENDAHULUAN}

Proses pendidikan di Indonesia turut ambil bagian dalam menyiapkan generasi muda sebagai penerus bangsa. Melalui sistem pendidikan yang telah disesuaikan dengan keadaan dan kondisi di tengah masyarakat. Indonesia telah menerapkan Kurikulum 2013 yang terdapat beberapa materi pembelajaran yang telah disesuaikan dengan kebutuhan kehidupan nyata.

Kurikulum 2013 telah dikembangkan dengan materi yang sesuai kebutuhan dalam kehidupan sehari-hari, perkembangan diri dan kebutuhan masa depan. Selain itu, pembelajaran saat ini dalam pelaksanaanya telah mengalami variasi mulai dari cara mengajar dan menyampaikan materi serta media yang digunakan bervariasi. Matematika adalah ilmu tentang bilangan-bilangan, hubungan antar bilangan dan prosedur operasional yang digunakan dalam penyelesaian masalah bilangan. Penerapan ilmu matematika dapat dilihat dalam persoalan kehidupan sehari-hari yang diuraikan dalam model matematika sehingga penyelesaiannya lebih cepat dan sederhana. Matematika melatih peserta didik untuk berpikir kritis, kreatif, inovatif, dan mampu menyelesaikan masalah dengan tepat, singkat, dan dapat dipertanggung jawabkan.

Menurut Peraturan Menteri Pendidikan dan Kebudayaan nomor 24 tahun 2016 tentang Kompetensi Inti dan Kompetensi Dasar pada Kurikulum 2013 Pendidikan Dasar dan Pendidikan Menengah Pasal 1 Butir 3 yaitu pelaksanaan pembelajaran pada Sekolah Dasar/Madrasah Ibtidaiyah (SD/MI) dilakukan dengan pendekatan pembelajaran tematik-integratif, kecuali mata pelajaran Matematika dan Pendidikan Jasmani, Olahraga dan Kesehatan sebagai mata pelajaran yang berdiri sendiri untuk kelas IV,V, dan VI. Pelaksanaannya diperkuat dengan surat pemberitahuan Kapuskurbuk No.8952/H3.3/PB/2016 bahwa buku tematik tidak lagi memasukkan KD Matematika dan PJOK di kelas IV,V dan VI. Meskipun matematika telah menjadi mata pelajaran sendiri terpisah dari buku tematik namun dalam proses pembelajarannya masih berorientasi 
pada pendekatan scientific yang terdiri dari: (1) Mengamati, (2) Menanya, (3) Mencoba, (4) Mengolah informasi, dan

Mengkomunikasikan.

Disisi lain matematika menjadi salah satu mata pelajaran yang dianggap sulit bagi peserta didik di Sekolah Dasar, baik dilihat dari segi materinya maupun dalam penyampaiannya. Sebagian peserta didik menganggap bahwa matematika adalah mata pelajaran yang menyenangkan dan mudah dengan cara berkonsentrasi dan sering berlatih. Matematika adalah ilmu pasti yang mengajarkan tentang ilmu hitung yang sehari-hari selalu digunakan mulai dari kehidupan di rumah, di sekolah maupun di masyarakat. Berdasarkan hasil observasi yang telah dilakukan di Kelas IV di 3 (tiga) Sekolah Dasar yang dilaksanakan pada tanggal 16 Februari 2019 sampai dengan 30 Maret 2019.

Berdasarkan hasil observasi diperoleh hasil sebagai berikut Sekolah Dasar Negeri 3 Karanganyar mengalami kendala saat pembelajaran matematika yaitu sebagian besar peserta didik mengalami kesulitan dalam menyelesaikan permasalahan matematika dalam soal cerita disebabkan kurangnya minat peserta didik untuk aktivitas literasi pada soal maupun teks materi, permasalahan pembulatan tingkat satuan, puluhan dan ratusan masih membutuhkan waktu yang lama untuk memahaminya dan mengerjakannya.

Sekolah Dasar Negeri Banyuanyar 3, Kota Surakarta mempunyai masalah masih terdapat peserta didik yang tidak mampu mengedalikan diri dalam fokus matematika, sehingga suasana kelas menjadi tidak kondusif. Sekolah Dasar Negeri 2 Tengklik, Tawangmangu. Peserta didik mengalami kesulitan dalam menangkap materi yang ada dalam mata pelajaran matematika. Baik saat penyampaian materi maupun dalam kegiatan evaluasi seperti menyelesaikan soal-soal matematika. Meskipun dalam menyampaian telah menggunakan media yang ada disekitar sekolah. Namun, peserta didik masih enggan untuk mengerjakan tugas dari guru berkaitan dengan matematika. 
Permasalahan yang berkaitan dengan rendahnya kemampuan berpikir kritis segera di atasi sehingga terjadi perubahan paradigma yang matematika sulit dipahami menjadi mudah. Maka dari itu, perlu adanya upaya mengatasi permasalahan melalui penerapan aktivitas literasi matematika agar kemampuan berpikir kritis peserta didik berkembang secara linier. Aktivitas menurut Anton M. Mulyono (2001:26) adalah kegiatan atau keaktifan. Literasi didefinisikan sebagai kemampuan untuk menggunakan bahasa dan gambar dalam bentuk yang kaya dan beragam untuk membaca, menulis, mendengarkan, berbicara, melihat, menyajikan dan berpikir kritis tentang ide-ide (Yunus Abidin, dkk., 2018:1). Sebagai wujud adanya literasi adalah dengan menunjukkan aktivitas literasi. Literasi matematika menurut The PISA Assesment framework: mathematics, Reading, Science and Problem solving knowledge and skill. Organisasi for Economic Cooperation an Development OECD,(20013e) dalam Bahrul Hayat dan Suhendra Yusuf (2015:45) Literasi matematika merupakan “... kemampuan untuk mengenal dan memahami peran matematika di dunia, untuk dijadikan sebagai landasan dalam menggunakan dan melibatkan diri dengan matematika sesuai dengan kebutuhan peserta didik sebagai warga negara yang konstruktif, peduli dan reflektif”.

Berdasarkan pendapat para ahli. Maka, aktivitas literasi matematika adalah sebuah kegiatan atau keaktifan dalam merumuskan, menyusun dan menafsirkan matematika sebagai kemampuan utama dalam belajar matematika. Menurut Carbrera (1992) dalam Maulana (2017:6) menyatakan bahwa "Berpikir kritis merupakan proses dasar dalam suatu keadaan dinamis yang memungkinkan peserta didik untuk menanggulangi dan mereduksi ketidaktentuan masa mendatang”. Menurut Ennis (1981) dalam Ahmad Susanto (2013), berpikir kritis adalah berpikir dengan tujuan membuat keputusan masuk akal tentang apa yang diyakini atau dilakukan. Menurut Schafersman (1991) dalam Ema Butsi Prihastari dan Ratna Widyaningrum (2015) keterampilan berpikir kritis adalah kemampuan untuk mengambil 
keputusan yang bernalar dalam situasi kompleks yang menekankan pada knowing how dan knowing what.

Kemampuan berpikir kritis merupakan kemampuan mendasar untuk mengambil keputusan masuk akal yang menekankan pada kowing how dan knowing what. Selanjutnya, Ennis (Ahmad Susanto, 2016) menyebutkan ada enam unsur dalam berpikir kritis yang dikaitkan dengan FRISCO, yaitu Focus (fokus), Reason (alasan), Inference (menyimpulkan), Situation (situasi), Clarity (kejelasan), dan Overview (pandangan menyeluruh). Adapun kerangka berpikir sebagai berikut: kondisi awal Pembelajaran masih konvensional menyebabkan kemampuan berpikir kritis dalam pelajaran matematika rendah dan matematika masih terasa sulit.

Dalam penelitian ini diberi perlakuan dengan Aktivitas literasi matematika untuk memahami masalah nyata melalui proses matematisasi. Hasil yang diharapkan Aktivitas literasi matematika berpengaruh terhadap kemampuan berpikir kritis peserta didik. Hipotesis penelitian dinyatakan terdapat pengaruh aktivitas literasi matematika terhadap kemapuan berpikir kritis pada mata pelajaran matematika kelas IV Sekolah Dasar Negeri 3 Karanganyar Tahun Pelajaran 2019/2020.

\section{METODE PENELITIAN}

Penelitian ini dilaksanakan di kelas IV Sekolah Dasar Negeri 3 Karanganyar. Peneliti memilih Sekolah Dasar Negeri 3 Karanganyar sebagai objek penelitian dengan alasan karena jarak yang dekat dan mudah diakses serta di Sekolah Dasar Negeri 3 Karanganyar ini dijumpai permasalahan yang harus segera diatasi mengenai rendahnya kemampuan berpikir kritis. Penelitian ini menggunakan bentuk penelitian kuantitatif dengan pendekatan preexperimental design. Desain yang digunakan dalam penelitian ini adalah One Group Pretest-Posttest Design. Penelitian dilakukan pada satu kelompok kelas dengan membandingkan keadaan sebelum perlakuan (Pretest) dan setelah diberi perlakuan (Posttest). Sampel yang digunakan adalah peserta didik Sekolah Dasar Negeri 3 Karanganyar 
kelas IV Tahun Pelajaran 2019/2020 dengan jumlah 36 peserta didik terdiri dari perempuan berjumlah 17 anak dan laki-laki 19 anak.

Teknik pengumpulan data dalam penelitian ini adalah: 1) Tes ini ditujukan kepada masing-masing peserta didik untuk mengukur kemampuan berpikir kritis dengan cara tes yang di-lakukan di awal pembelajaran (pretest) dan tes yang di-lakukan di akhir pembelajaran (posttest). Kemudian hasil dari posttest sebagai data ketercapaian peserta didik dalam kemampuan berpikir kritis.. Tes yang digunakan dalam penelitian ini adalah tes berbentuk uraian yaitu pertanyaan yang menuntut peserta didik menjawab dalam bentuk menguraikan, menjelaskan, mendiskusikan, membandingkan, memberikan alasan dan bentuk lain yang sejenis menurut Sudjana (Hamid Abdul, 2019:30); 2) Observasi sebagai teknik pengumpulan data mem-punyai ciri yang spesifik bila dibandingkan dengan teknik yang lain, yaitu wawancara dan kuesioner. Observasi ini penulis menggunakan instru-men observasi terstruktur.
Observasi terstruktur adalah observasi yang telah dirancang secara sistematis terhadap variabel aktivitas literasi matematika. Jadi, observasi terstruktur di-lakukan apabila penulis telah tahu dengan pasti tentang variabel apa yang akan diamati. Observasi ini digunakan untuk memperoleh data tentang aktivitas literasi matematika melalui proses matematisasi. Observasi dilaksanakan pada saat proses pembelajaran berlangsung; 3) Dokumentasi digunakan untuk memperoleh data langsung dari tempat penelitian, meliputi buku-buku yang relevan, peraturan-peraturan, laporan kegiatan, foto-foto selama penelitian, RPP, data administrasi kelas seperti: daftar hadir siswa, jadwal piket, jadwal pelajaran di Sekolah Dasar Negeri 03 Karanganyar, 4) Wawancara dilakukan pada awal penelitian dan selama penelitian sehingga diperoleh informasi yang akurat, meliputi permasalahan yang dihadapi, kondisi lingkungan di sekitar sekolah dan kekurangan atau kelemahan yang terdapat di Sekolah Dasar Negeri 3 Karanganyar. validitas adalah suatu ukuran dalam uji coba instrumen 
untuk mencari validitas, sehingga menunjuk-kan tingkat kevalidan atau keabsahan suatu instrumen

Uji coba instrumen dilakukan dengan validitas isi. Karena menggunakan instrumen tes essay. Untuk mengukur reliabilitas dalam penelitian ini menggunakan rumus korelasi Alpha Cronbach. Menurut Sugiyono, (2015: 147 ) Dalam penelitian kuantitatif, analisis data merupakan kegiatan setelah data dari seluruh responden atau sumber data lain terkumpul. Pengujian dalam analisis data ada dua bagian yaitu uji prasyarat analisis dan uji hipotesis. Uji normalitas data untuk mengetahui normal tidaknya data dari pre-test dan post-Test. Syarat data dikatakan berdistribusi normal jika signifikan atau nilai > 0.05. Uji homogenitas menurut Fajri Ismail (2018;201) bahwa homogenitas data mempunyai makna bahwa data memiliki variasi atau keragaman dengan nilai yang sama atau secara statistik sama. Uji hipotesis dalam penelitian ini menggunakan Uji Paired Sample ttest untuk mencari pengaruh atau membandingkan hasil pre test dan post test. Penelitian ini menggunakan tes dengan teknik One Group PretestPosttest Design.

\section{HASIL DAN PEMBAHASAN}

1. Deskriptif Data Tentang Kemampuan Berpikir Kritis Sebelum Penerapan Aktivitas Literasi Matematika pada Mata Pelajaran Matematika

Perolehan hasil nilai Pretest kemampuan berpikir kritis sebelum penerapan aktivitas literasi matematika peserta didik kelas IV Sekolah Dasar Negeri 3 Karanganyar Tahun Pelajaran 2019/2020 menunjukkan bahwa nilai minimum yang diperoleh adalah 30, nilai maksimal 78 dengan mean 51, 8 , median 53, modus 36 dan standar deviasi 13,7. Adapun tabel Nilai Pretest Kemampuan Berpikir Kritis pada mata pelajaran matematika, sebagai berikut: 
Tabel 1. Tabel nilai Pretest

Kemampuan Berpikir Kritis pada mata pelajaran matematika

\begin{tabular}{lc} 
& Pretest \\
\hline Maximal & 78 \\
\hline Mininum & 30 \\
\hline Mean & 51,8 \\
\hline Median & 53 \\
\hline Modus & 36 \\
\hline Standar & \\
Deviasi & 13,7 \\
\hline
\end{tabular}

Distribusi perolehan hasil nilai pretest yaitu nilai $30-37$ sebanyak 8 peserta didik dengan Persentase 22\%; nilai 38-45 sebanyak 3 peserta didik dengan Persentase $8 \%$; nilai $46-53$ sebanyak 7 peserta didik dengan Persentase $19 \%$ nilai 54-62 sebanyak 11 peserta didik dengan Persentase $31 \%$; nilai 61-68 sebanyak 1 dengan Persentase $3 \%$; nilai 69-76 sebanyak 5 peserta didik dengan Persentase $14 \%$; nilai 77-84 sebanyak 1 peserta didik dengan presetase $3 \%$. Total jumlah Persentase sebanyak 100\%. Adapun tabel Distribusi Frekuensi Hasil Pretest Kemampuan Berpikir Kritis pada mata pelajaran matematika sebagai berikut:
Tabel 2. Distribusi Frekuensi Hasil Pretest Kemampuan Berpikir Kritis pada mata pelajaran matematika

\begin{tabular}{lcc} 
Nilai & Frekuensi & Persentase \\
\hline $30-37$ & 8 & $22 \%$ \\
\hline $38-45$ & 3 & $8 \%$ \\
\hline $46-53$ & 7 & $19 \%$ \\
\hline $54-62$ & 11 & $31 \%$ \\
\hline $61-68$ & 1 & $3 \%$ \\
\hline $69-76$ & 5 & $14 \%$ \\
\hline $77-84$ & 1 & $3 \%$ \\
\hline
\end{tabular}

2. Deskriptif Data Tentang Kemampuan Berpikir Kritis Setelah Penerapan Aktivitas Literasi Matematika pada Mata Pelajaran Matematika

Hasil perolehan nilai hasil sebagai berikut: nilai terkecil diperoleh 58, nilai terbesar adalah 90 dengan mean 78,4 ; median 80; modus 82 dan standar deviasi 7,89. Adapun tabel deskriptif data tentang kemampuan berpikir kritis setelah penerapan aktivitas literasi matematika pada mata pelajaran matematika sebagai berikut: 
Tabel 3. Tabel Nilai Posttest

Kemampuan Berpikir Kritis pada Mata Pelajaran Matematika

\begin{tabular}{lc} 
& Nilai \\
\hline Maximal & 90 \\
\hline Minimal & 58 \\
\hline Mean & 78,444 \\
\hline Median & 80 \\
\hline Modus & 82 \\
\hline Standar Deviasi & 7,8865
\end{tabular}

Data distribusi frekuensi data jumlah peserta didik sebanyak 36 orang diantaranya mendapatkan nilai antara 58-62 sebanyak 2 peserta didik dengan Persentase $6 \%$, nilai antara 63-67 sebanyak 1 peserta didik dengan preesntase $3 \%$, nilai antara $68-72$ sebanyak 6 peserta didik dengan Persentase $17 \%$, nilai 73-77 sebanyak 3 peserta didik dengan Persentase $8 \%$, nilai antara 78-82 sebanyak15 peserta didik dengan Persentase $42 \%$, nilai 83-87 sebanyak 4 peserta didik dengan Persentase $11 \%$, dan 88-92 sebanyak 5 dengan Persentase $14 \%$. Total jumlah presentse dalah 100\%. Adapun tabel distribusi frekuensi hasil posttest kemampuan berpikir kritis pada mata pelajaran matematika sebagai berikut:
Tabel 4. Tabel distribusi frekuensi hasil post-test kemampuan berpikir kritis pada mata pelajaran matematika

\begin{tabular}{lcc} 
Nilai & F & Persentase \\
\hline $58-62$ & 2 & $6 \%$ \\
\hline $63-67$ & 1 & $3 \%$ \\
\hline $68-72$ & 6 & $17 \%$ \\
\hline $73-77$ & 3 & $8 \%$ \\
\hline $78-82$ & 15 & $42 \%$ \\
\hline $83-87$ & 4 & $11 \%$ \\
\hline $88-92$ & 5 & $14 \%$ \\
\hline Total & 36 & $100 \%$ \\
\hline
\end{tabular}

Pengujian Hipotesis

1. Uji Prasyarat

a. Uji Normalitas

Uji normalitas data menggunakan teknik One Sample Kolmogorov Smirnov. Hasil uji normalitas data mengunakan rumus Kolmogorov-Smirnov menggunakan SPSS versi 20 menghasilkan nilai signifikansi kemampuan berpikir kritis (pretest) sebesar 0,593>0,05 sehingga, data berdistribusi normal. Nilai signifikansi kemampuan berpikir kritis (posttest) sebebsar 0,865 >0,05 sehingga, data berdistribusi normal.

Berdasarkan hasil perhitungan uji normalitas 
diatas dapat disimpulkan, bahwa nilai signifikansi kemampuan berpikir kritis (pretest) dan nilai signifikansi kemampuan berpikir kritis (posttest) berdistribusi normal.

b. Uji homogenitas

Data Homogenitas diasumsikan bahwa peserta didik kelas IV Sekolah Dasar Negeri 03 Karanganyar Tahun Pelajaran 2019/2020 dikatakan homogen karena, secara bersama melaksanakan proses pembelajaran dari guru yang sama. Kelas berjalan dalam kurun waktu tertentu dalam hal ini selama dua semester. Perkembangan peserta didik dalam rentang usia 9-10 tahun secara teoritik relatif sama. Pertumbuhan fisik yang setara. Materi yang disampaikan menggunakan metode yang sama.

c. Uji Paired Sample t-test

Penelitian ini menggunakan Uji paired sample t-test untuk mencari pengaruh atau membandingkan hasil pretest dan posttest. Analisis menggunakan Uji paired sample t-test ini untuk mengetahui pengaruh aktivitas literasi matematika terhadap kemampuan berpikir kritis pada mata pelajaran matematika kelas IV SD N 3 Karanganyar Tahun Pelajaran 2019/2020. Uji paired sample t-test digunakan untuk menguji hipotesis penelitian meng-gunakan bantuan aplikasi SPSS versi 20. Data hasil hitung menggunakan uji $\mathrm{t}$, diperoleh nilai $\mathrm{t}$ hitung sebesar 24,24 dan nilai $\mathrm{t}$ tabel sebesar 1,69. apabila, nilai $\mathrm{t}$ hitung sebesar 24,24> nilai $\mathrm{t}_{\text {tabel }}$ sebesar 1,69, Maka Ho ditolak dan $\mathrm{Ha}$ diterima, dinyatakan dengan hipotesis alternatif (Ha) "Ada pengaruh aktivitas literasi matematika terhadap kemampuan berpikir kritis pada mata pelajaran matematika kelas IV Sekolah Dasar Negeri 3 Karanganyar Tahun Pelajaran 2019/2020" dinyatakan dapat diterima kebenarannya pada taraf signifikansi $5 \%$. 


\section{SIMPULAN}

Hasil penelitian pre-test

kemampuan berpikir kritis yang telah dilaksanakan mendapatkan hasil rata-rata 51,83 dan rata-rata nilai posttest kemampuan berpikir kritis adalah 78,44. Sehingga hasil posttest sebesar 78,44 > hasil pretest sebesar 51,83 dengan demikian, rata-rata post-test meningkat sebanyak 26,61. Dapat dinyatakan bahwa terdapat perbedaan yang signifikan pada nilai tes yang diberikan kepada peserta didik. Berdasarkan analisis data menggunakan aplikasi SPSS v.20 diperoleh nilai $t_{\text {hitung }}=24,24$ kemudian dibandingkan dengan nilai $t_{\text {tabel }}$ pada taraf signifikansi $5 \%$ yaitu 1,69. Mendapatkan hasil bahwa $\mathrm{t}_{\text {hitung }}>\mathrm{t}_{\text {tabel }}$.

Dapat dinyatakan Ha diterima dan Ho ditolak. Ha yang dinyatakan ada pengaruh aktivitas literasi matematika terhadap kemapuan berpikir kritis pada mata pelajaran matematika kelas IV Sekolah Dasar Negeri 3 Karanganyar Tahun Pelajaran 2019/2020 terbukti kebenarannya pada taraf signifikan $5 \%$. Sehingga hipotesis dapat diterima.
Adapun saran yang dapat diberikan dalam penelitian antara lain: 1) bagi peserta didik diharapkan lebih fokus dan disiplin dalam pembelajaran. Setiap intruksi dari guru dapat dilaksanakn dengan baik. Setiap ada kesempatan bertanya dalam diskusi, harus aktif dan kritis ketika menjumpai materi atau penjelasan yang belum dimengerti; 2) bagi guru proses pembelajaran yang masih konvesional harus diimbangi dengan metode-metode yang sesuai dengan kurikulum 2013. Memberikan latihan soal dan membiasakan peserta didik untuk mengerjakan soal cerita. Menerapkan aktivitas literasi matematika dengan berdiskusi maupun dengan model pembelajaran yang lain. Agar peserta didik terbiasa untuk memahami dan mampu untuk menyelesaikan permasalahan matematika; 3) Untuk penelitian selanjutnya dapat menerapkan aktivitas literasi matematika untuk menguji kemampuan yang lain atau menggunakan metode, model dan strategi pembelajaran yang sesuai. Sehingga terdapat beberapa alternatif untuk mengatasi permasalahan yang sama. 
DAFTAR PUSTAKA

Ahmad Susanto.2016. Teori Belajar dan Pembelajaran di Sekolah Dasar.Jakarta:

PRENADAMEDIA GROUP.

Anton M. Mulyono. 2001. Aktivitas Belajar. Bandung:Yrama

Bahrul Hayat \& Suhendra Yusuf. 2015. Benchmark Internasional Mutu Pendidikan. Jakarta: Bumi Aksara.

Ema Butsi Prihastari dan Ratna Widyaningrum. 2015. Analisis Berpikir Kritis Siswa Kelas V pada Materi Geometri dengan Teknik Scaffolding. Jurnal Widya Wacana PGSD Universitas Slamet Riyadi. 10 (1)

Fajri Ismail. 2018. Statistika untuk Penelitian Pendidikan dan Ilmu-ilmu Sosial. Jakarta:Prenadamedia Group

Hamid Abdul. 2019. Penyusunan Tes Tertulis (Paper and Pencil Test). Jawa Timur: Uwais Inspirasi Indonesia.

Kementrian Pendidikan dan Kebudayaan. 2016. Peraturan Menteri Pendidikan Dan Kebudayaan Republik Indonesia Nomor 24 Tahun 2016 Tentang Kompetensi Inti Dan Kompetensi Dasar Pelajaran Pada Kurikulum 2013 Pada Pendidikan Dasar Dan Pendidikan Menengah. Jakarta: Kementrian Pendidikan dan Kebudayaan.
Maulana. 2017. Konsep Dasar Matematika dan Pengembangan Kemampuan Berpikir Kritis-Kreatif. Sumedang: UPI Sumedang Press.

Sugiyono. 2015. Metode Penelitian Pendidikan Pendekatan Kuantitatif, Kualitatif, dan $R$ $\& D$. Bandung: Alfabeta.

Yunus Abidin, Tita Mulyati dan Hana Yunansah. 2018. PEMBELAJARAN LITERASI: Strategi Meningkatkan Kemampuan Literasi Matematika, Sains, Membaca, dan Menulis. Jakarta: Bumi Aksara. 